\title{
Studies on Respiration Rate of Field Beans at Different Temperatures
}

\author{
R. Nisha* , C. Nickhil and M. Ramachandra \\ University of Agricultural Sciences Bangalore, Karnataka, India \\ *Corresponding author
}

\begin{tabular}{|c|c|}
\hline & A B S T R A C T \\
\hline & \multirow{7}{*}{$\begin{array}{l}\text { Field bean also known as Dolichos lablab beans is one of the important legume crops } \\
\text { grown widely in Southern Karnataka. It is rich in carbohydrate, protein, fat, and crude } \\
\text { fiber. Fresh beans are a favoured vegetable of the people of this region. But, its availability } \\
\text { is being seasonal, attempts are made to preserve its freshness for longer periods. The } \\
\text { storage life of vegetables and fruits depends on their respiration rates. Respiration is a } \\
\text { physiological process, involving the oxidation of the organic tissues evolving } \mathrm{CO}_{2} \text {, water } \\
\text { and energy. Hence studies were made to determine the respiration rate of field beans at } \\
\text { different temperatures }\left(24,10 \text { and } 3^{\circ} \mathrm{C}\right) \text {. Experiments were conducted by storing } 350 \mathrm{~g} \text { of } \\
\text { field beans, in laboratory storage chambers of } 1000 \mathrm{ml} \text { capacity. Gas concentrations of } \mathrm{CO}_{2} \\
\text { and } \mathrm{O}_{2} \text { were measured at regular intervals and respiration rates were computed. The results } \\
\text { indicated that the respiration rates were } 29.14,53.17 \text { and } 85.15 \mathrm{mg} \mathrm{CO} \mathrm{CO}_{2} / \mathrm{kg} \text { - } \mathrm{h} \text { at } 3,10 \text { and } \\
24^{\circ} \mathrm{C} \text {, respectively at the beginning of the experiment, which gradually decreased during } \\
\text { the storage period. The rate of decrease of respiration rate was found to be low at lower } \\
\text { temperatures. }\end{array}$} \\
\hline & \\
\hline $\begin{array}{l}\text { Field beans, } \\
\text { Respiration rate, } \\
\text { Temperature, } \\
\mathrm{O}_{2}, \mathrm{CO}_{2} \text {. }\end{array}$ & \\
\hline Article Info & \\
\hline & \\
\hline & \\
\hline 10 October & \\
\hline
\end{tabular}

\section{Introduction}

Field bean are bushy, perennial herb and semi-erect crop. It is mainly cultivated either as a pure crop or mixed with finger millet, groundnut, castor, corn bajra in Asia and Africa. The crop is mainly grown for pulse, vegetable and forage. The crop is grown for its green pod, while dry seed are used in various vegetable food preparations. It is one of the major source of protein in the diet in southern states of India. The consumer preference is mainly due to the pod fragrance. One of the cherished vegetable of south Karnataka people is field beans. It has a characteristic aroma of its own which is relished by the people. Field bean (Dolichos lablab) belonging to the family Fabaceae, is one of the most ancient legume crops.
It is a multipurpose crop grown for pulse, vegetable and forage. The crop is mainly grown for its green pods, while dry seeds are used in various vegetable food preparations. The beans are a good source of protein $(24 \%)$ carbohydrate $(18 \%)$ and starch (48 \%) (Purseglove, 1968).

The fruits and vegetables lose their freshness when stored under ambient conditions, because of physiological and biochemical changes like transpiration and respiration. Respiration rate plays an important role in maintaining the freshness and quality of fruits and vegetables. The respiration rate can be controlled by reducing the temperature and / or gas compositions surrounding the product. 
Temperature management is one of the most important tools for extending the shelf life of fruits (Lee and Kader, 2000).

Many studies on the effect of storage temperature on quality and storage life of fruits have been done which indicated that the temperature plays an important role on quality of fruits after harvest (Dixon et al., 2004). Ripening is a complex physiological process that increases the softening, colouring, sweetening and aromatic compounds in most of the fruits and vegetables. The respiration is a metabolic process by which organic material in living cells are continuously broken down by utilizing $\mathrm{O}_{2}$ and evolving $\mathrm{CO}_{2}, \mathrm{H}_{2} \mathrm{O}$ and energy. The metabolic reaction during respirations is shown below:

$\mathrm{C}_{6} \mathrm{H}_{12} \quad \mathrm{O}_{6}+6 \mathrm{O}_{2} \rightarrow 6 \mathrm{CO}{ }_{2}+6 \mathrm{H}_{2} \mathrm{O}+686$ $\mathrm{kcal} / \mathrm{mole}(1)$

The metabolism of respiration may cause some physical/chemical changes such as weight loss, which reduce value of fruits and vegetables especially at room temperature (Khan \& Ahmad, 2005). Different fruits and vegetables have different respiration rates. Respiration rate of fresh produce can be express as $\mathrm{O}_{2}$ consumption rates. The storage life of commodities varies inversely with the rate of respiration. This is because of the reason that respiration supplies compounds that determine the rate of metabolic processes directly related to quality parameters such as firmness, sugar content, aroma, and flavor.

Commodities with higher rates of respiration tend to have shorter storage life than those with lower rates of respiration. Storage life of broccoli, lettuce, peas, spinach, and sweet corn, all of which have high respiration rates, is short in comparison to that of apples, cranberries, limes, onions, and potatoes, which have low respiration rates.

\section{Materials and Methods}

\section{Materials}

Fresh, well matured, Field beans (Dolichos lablab), were procured from Yelhanka market, Bengaluru which were available after 1 or 2 days of harvest. The pods were separated from the whole beans before the storage experiment. The physical dimensions like size, average weight and bulk density are measured for the samples selected for the respiration studies. For the respiration rate studies, experimental storage chambers consisted of PET jars of $1000 \mathrm{ml}$ capacity with an airtight plastic lid. Teflon tape was wrapped around the mouth of the jars to seal the lids for air tightness.

\section{Experimental set up}

The respiration study was done to calculate the respiration rate of field beans as described by Bhukan Jyothi, (2008) and Ramachandra, (1995). The respiration rates of the field beans were measured at low ( 3 and $10{ }^{\circ} \mathrm{C}$ ) and ambient $\left(24{ }^{\circ} \mathrm{C}\right)$ temperatures. For the respiration rate studies, experimental storage chambers consisted of PET jars of $1000 \mathrm{ml}$ capacity with an airtight plastic lid. Teflon tape was wrapped around the mouth of the jars to seal the lids for air tightness. A hole of $5 \mathrm{~mm}$ diameter was drilled on each of the lid and a septum (silicon rubber) was fixed firmly. The septum facilitated the insertion of the needle of the gas analyzer for measurement of gas concentration, inside the chamber. Field beans of known weight (350 g) were placed inside the experimental storage chambers with lids closed lids. Each set of three replications were placed in low ( 3 and $\left.10{ }^{\circ} \mathrm{C}\right)$ and ambient temperature $\left(24^{\circ} \mathrm{C}\right)$. Beans were allowed to respire inside the experimental storage chambers, the gas concentrations inside the chambers were 
measured using $\mathrm{O}_{2}-\mathrm{CO}_{2}$ Gas Analyzer (Make: PBI Dan sensor, UK; Model: Checkmate II). The gas samples were drawn from zeroth hour and at every $30 \mathrm{~min} . \mathrm{O}_{2}$ $\mathrm{CO}_{2}$ Gas Analyzer (Make: PBI Dan sensor, UK, Model: Check Mate II) is automatic and easy to use. When the syringe is introduced into the material package, the built-in pump automatically starts sampling the gas, ensuring an easy and accurate operation. The gas analysis result is shown in the built-in LCD display and also stored in the memory. The results can then be exported to an external computer via the USB data connection or saved on a memory stick, or printed on the built-in printer. The $\mathrm{O}_{2}-\mathrm{CO}_{2}$ Analyzer, Check Mate II, consists of a zirconia (Zr) sensor (Fig. 2). The $\mathrm{Zr}$ sensor operates like a solid state battery which produces a small voltage or electro motive force (EMF) in the presence of oxygen.

$$
\begin{aligned}
& \mathrm{RR}=\frac{1.43 \times \text { head space concentration of } \mathrm{O}_{2} \times \mathrm{V} \times 60}{\mathrm{w} \times \mathrm{t} \times 100} \\
& \mathrm{RR}=\frac{2 \mathrm{x} \text { head space concentration of } \mathrm{CO}_{2} \times \mathrm{V} \times 60}{\mathrm{w} \times \mathrm{t} \times 100}
\end{aligned}
$$

Where,

$\mathrm{RR}=$ Respiration rate, $\left(\mathrm{mg} \mathrm{O}_{2} / \mathrm{kg}-\mathrm{h}\right)$

$\mathrm{V}=$ Free volume of the chamber $(\mathrm{ml})$

$\mathrm{w}=$ Mass of the stored product $(\mathrm{kg})$

$\mathrm{t}=$ Time $(\mathrm{min}), \mathrm{CO}_{2} \& \mathrm{O}_{2}=$ concentrations inside the chamber, $(\mathrm{mg} / \mathrm{l})$

\section{Results and Discussion}

\section{Physical properties}

The Length 7.5- $13 \mathrm{~mm}$, Width 3.4- $8.5 \mathrm{~mm}$ and Thickness 1.8- $5.6 \mathrm{~mm}$. The shape of the bean can be inferred as nearly oval as represented in the standard chart. The bulk density, true density and unit weight of the field beans (100 seeds), were $180.3 \pm 0.8 \mathrm{~kg} /$ $\mathrm{m}^{3}, 360.5 \pm 0.2 \mathrm{~kg} / \mathrm{m}^{3}$ and $40 \pm 6.5 \mathrm{~g}$, respectively

\section{Progression of $\mathrm{O}_{2}$ and $\mathrm{CO}_{2}$ concentrations} $(\%)$ in the storage chambers

The variations of gas concentrations in airtight storage chambers are presented in table 1 . The variations in gas concentrations are mainly due to the chemical reactions undergoing in the storage chambers. Results clearly indicated a fast depletion of $\mathrm{O}_{2}$ and increase of $\mathrm{CO}_{2}$ inside the closed chamber.

This trend was high at $24{ }^{\circ} \mathrm{C}$ compared to 10 and $3{ }^{\circ} \mathrm{C}$. The $\mathrm{CO}_{2}$ production rate and $\mathrm{O}_{2}$ consumption rate has a great influence on temperature. At higher temperature $\mathrm{CO}_{2}$ consumption was higher. According to Lakakul et al., 1998 the increase in $\mathrm{CO}_{2}$ concentration in the storage chamber jar will increase the heat which will enhance the rate of respiration. The $\mathrm{O}_{2}$ consumption rate increased significantly with increase in the storage temperature inside the storage chambers with the field beans being stored. The reduction of $\mathrm{O}_{2}$ and increase in the $\mathrm{CO}_{2}$ will spoil the product quality due to the internal heat evolved from the tissues by the process of respiration, Yang et al., (1988).

\section{Respiration rates}

The results clearly indicate that the respiration rate is dependent on the storage temperature, higher the temperature of storage higher the respiration rate. The $\mathrm{O}_{2}$ and $\mathrm{CO}_{2}$ concentrations were predicted from 0 to $69 \mathrm{hr}$ for all experimental combinations. Using the equations (2) and (3) the respiration rate for the gas concentrations was calculated (Fig. 1). 
Table.1 Gas Concentrations of Field beans stored in PET jars at temperatures 24,10 and $3{ }^{\circ} \mathrm{C}$

\begin{tabular}{|c|c|c|c|c|c|c|}
\hline \multirow{2}{*}{ Time (h) } & \multicolumn{6}{|c|}{ Gas Concentrations of Field beans stored in PET jars } \\
\cline { 2 - 7 } & \multicolumn{2}{|c|}{$24^{\circ} \mathbf{C}$} & \multicolumn{2}{c|}{$10^{\circ} \mathbf{C}$} & \multicolumn{2}{c|}{$3^{\circ} \mathbf{C}$} \\
\cline { 2 - 7 } & $\mathbf{C O}_{\mathbf{2}}(\boldsymbol{\%})$ & $\mathbf{O}_{\mathbf{2}}(\boldsymbol{\%})$ & $\mathbf{C O}_{\mathbf{2}}(\boldsymbol{\%})$ & $\mathbf{O}_{\mathbf{2}}(\boldsymbol{\%})$ & $\mathbf{C O}_{\mathbf{2}}(\boldsymbol{\%})$ & $\mathbf{O}_{\mathbf{2}}(\boldsymbol{\%})$ \\
\hline 0 & 0.00 & 20.10 & 0.00 & 20.10 & 0.00 & 20.10 \\
\hline 3 & 0.04 & 19.5 & 0.05 & 19.50 & 0.04 & 20.02 \\
\hline 6 & 6.0 & 12.4 & 3.80 & 16.50 & 1.08 & 19.30 \\
\hline 9 & 10.0 & 1.6 & 4.90 & 15.22 & 2.50 & 19.00 \\
\hline 12 & 11.3 & 1.49 & 5.08 & 14.70 & 2.56 & 18.80 \\
\hline 15 & 12.6 & 1.38 & 5.20 & 14.40 & 2.62 & 18.70 \\
\hline 18 & 13.9 & 1.27 & 5.50 & 14.00 & 2.68 & 18.70 \\
\hline 21 & 15.2 & 1.16 & 5.80 & 13.80 & 2.74 & 18.70 \\
\hline 24 & 16.5 & 1.05 & 6.10 & 13.20 & 2.80 & 18.60 \\
\hline 27 & 18.0 & 0.99 & 6.40 & 13.50 & 2.86 & 18.65 \\
\hline 30 & 25.0 & 0.35 & 6.70 & 12.10 & 2.92 & 18.40 \\
\hline 33 & 30.0 & 0.35 & 7.00 & 10.01 & 3.50 & 18.12 \\
\hline 36 & 32.0 & 0.29 & 7.30 & 9.10 & 3.89 & 18.10 \\
\hline 39 & 34.0 & 0.28 & 7.60 & 9.20 & 3.92 & 17.80 \\
\hline 42 & 36.0 & 0.27 & 7.90 & 9.50 & 3.98 & 17.60 \\
\hline 45 & 38.0 & 0.26 & 8.20 & 9.70 & 4.19 & 17.58 \\
\hline 48 & 55.0 & 0.25 & 8.10 & 9.80 & 4.26 & 17.10 \\
\hline 51 & 65.0 & 0.28 & 8.40 & 9.98 & 4.50 & 16.90 \\
\hline 54 & 65.6 & 0.16 & 8.70 & 8.67 & 4.80 & 16.80 \\
\hline 57 & 66.2 & 0.13 & 10.20 & 8.20 & 5.10 & 16.70 \\
\hline 60 & 66.8 & 0.12 & 10.27 & 8.10 & 5.40 & 16.60 \\
\hline 63 & 67.4 & 0.11 & 10.34 & 8.50 & 5.70 & 16.50 \\
\hline 66 & 68.0 & 0.11 & 10.50 & 8.80 & 6.00 & 16.50 \\
\hline 69 & 69.0 & 0.12 & 10.78 & 7.10 & 6.20 & 16.50 \\
\hline
\end{tabular}

Table.2 With the cubic model $\mathrm{R}^{2}$ value indicated the best for $3^{\circ} \mathrm{C}$ temperature

\begin{tabular}{|c|c|c|}
\hline Temperature $\left({ }^{\circ} \mathrm{C}\right)$ & Gas Concentrations $(\%)$ & $\mathrm{R}^{2}$ \\
\hline \multirow{2}{*}{$24^{\circ} \mathbf{C}$} & $\mathbf{O}_{2}$ & 0.873 \\
\cline { 2 - 3 } & $\mathbf{C O}_{2}$ & 0.968 \\
\hline \multirow{2}{*}{$10^{\circ} \mathbf{C}$} & $\mathbf{O}_{2}$ & 0.951 \\
\cline { 2 - 3 } & $\mathbf{C O}_{2}$ & 0.953 \\
\hline \multirow{2}{*}{$3{ }^{\circ} \mathbf{C}$} & $\mathbf{O}_{2}$ & 0.966 \\
\cline { 2 - 3 } & $\mathbf{C O}_{2}$ & 0.965 \\
\hline
\end{tabular}


Table.3 Respiration rates of Field beans for 30min time interval in $\mathrm{mg} \mathrm{CO}_{2} / \mathrm{kg}-\mathrm{h}$

\begin{tabular}{|c|c|c|c|}
\hline Time (h) & $\mathrm{RCO}_{2}$ at $24^{\circ} \mathrm{C}$ & $\mathrm{RCO}_{2}$ at $10^{\circ} \mathrm{C}$ & $\mathrm{RCO}_{2}$ at $3^{\circ} \mathrm{C}$ \\
\hline 0 & - & - & - \\
\hline 3 & 85.71 & 53.57 & 29.14 \\
\hline 6 & 71.42 & 35.00 & 17.85 \\
\hline 9 & 53.80 & 24.19 & 12.19 \\
\hline 12 & 45.00 & 18.57 & 9.35 \\
\hline 15 & 39.71 & 15.71 & 7.65 \\
\hline 18 & 36.19 & 13.80 & 6.52 \\
\hline 21 & 33.67 & 12.44 & 5.71 \\
\hline 24 & 32.14 & 11.42 & 5.10 \\
\hline 27 & 39.68 & 10.63 & 4.63 \\
\hline 30 & 42.85 & 10.00 & 5.00 \\
\hline 33 & 41.55 & 9.48 & 5.05 \\
\hline 36 & 40.47 & 9.04 & 4.66 \\
\hline 39 & 39.56 & 8.68 & 4.37 \\
\hline 42 & 38.77 & 8.36 & 4.27 \\
\hline 45 & 36.95 & 7.71 & 4.05 \\
\hline 48 & 35.35 & 7.50 & 4.01 \\
\hline 51 & 33.94 & 7.31 & 4.03 \\
\hline 54 & 32.69 & 8.09 & 4.04 \\
\hline 57 & 31.57 & 7.72 & 4.06 \\
\hline 60 & 30.14 & 7.38 & 4.07 \\
\hline 63 & 29.25 & 7.14 & 4.08 \\
\hline 66 & 28.05 & 7.00 & 4.02 \\
\hline 69 & 41.07 & 7.63 & 3.88 \\
\hline
\end{tabular}

Fig.1 Storage chambers for respiration rate studies

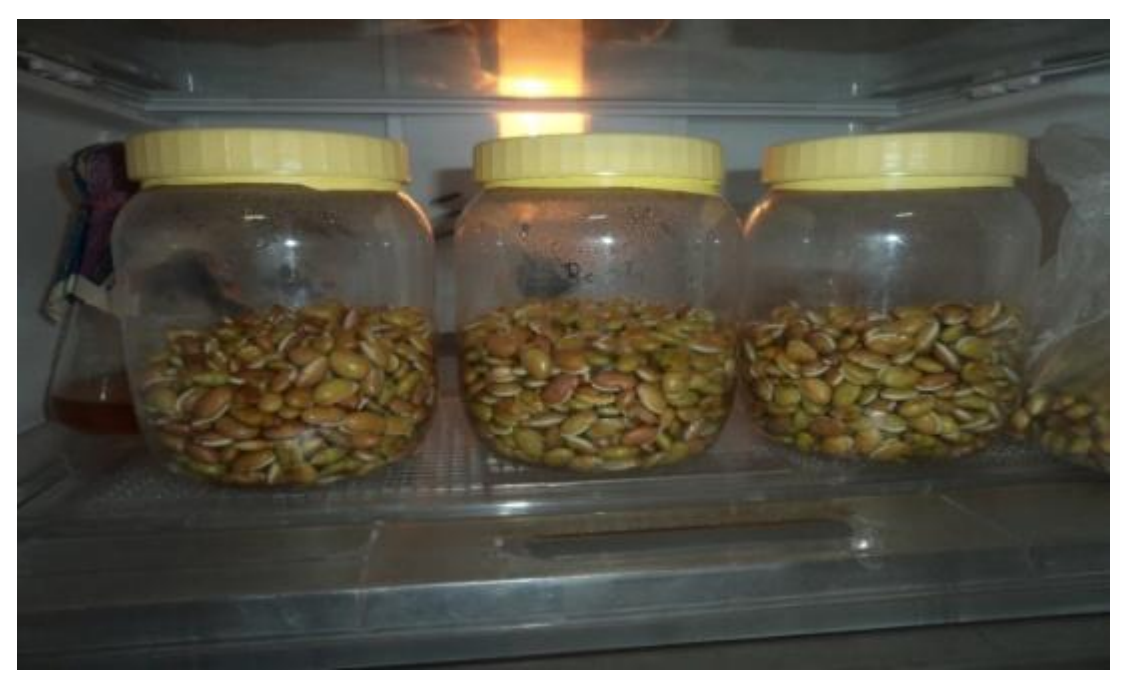


Fig. $2 \mathrm{O}_{2}$ and $\mathrm{CO}_{2}$ Gas Analyzer

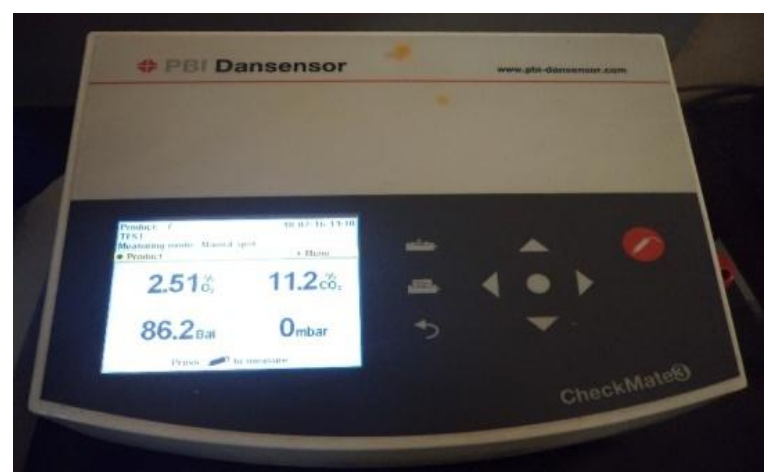

Fig.3 Influence of $\mathrm{CO}_{2}$ concentration with respect to time at different temperatures $\left(24,10\right.$ and $\left.3^{\circ} \mathrm{C}\right)$ on Field beans

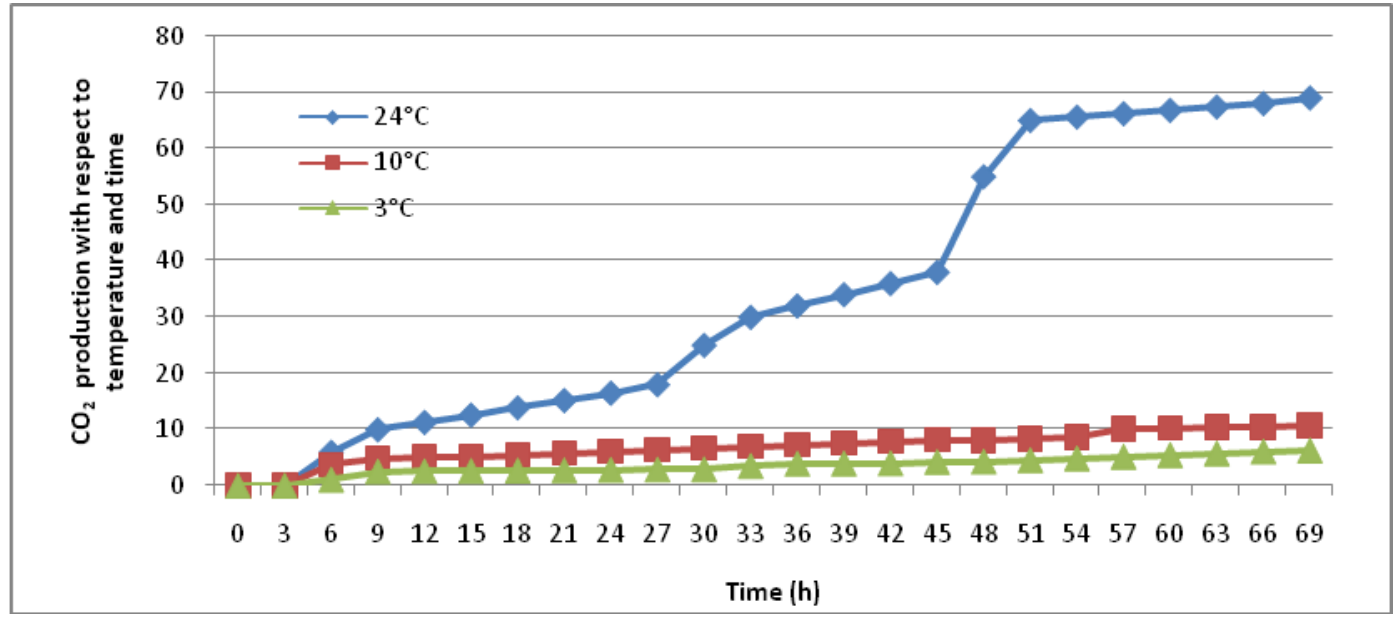

Fig.4 Influence of $\mathrm{O}_{2}$ concentration with respect to time at different temperatures $\left(24,10\right.$ and $\left.3^{\circ} \mathrm{C}\right)$ on Field beans

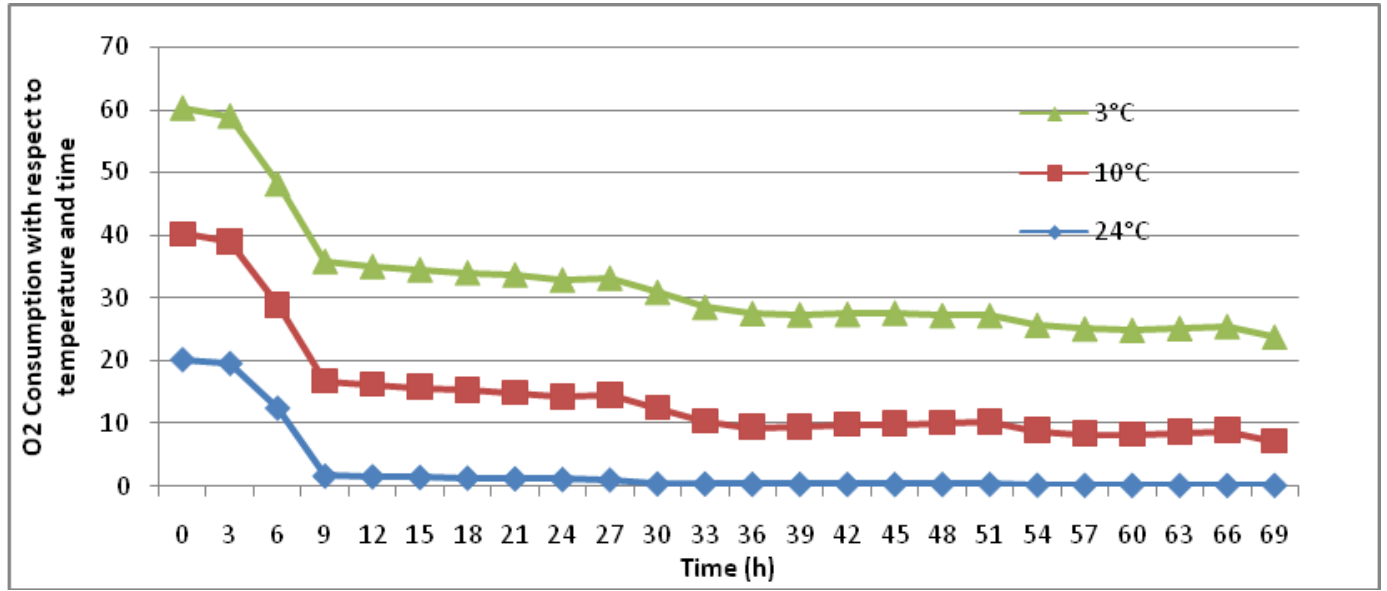


Fig.5 Respiration Rate of field beans in terms $\mathrm{CO}_{2}$ concentration

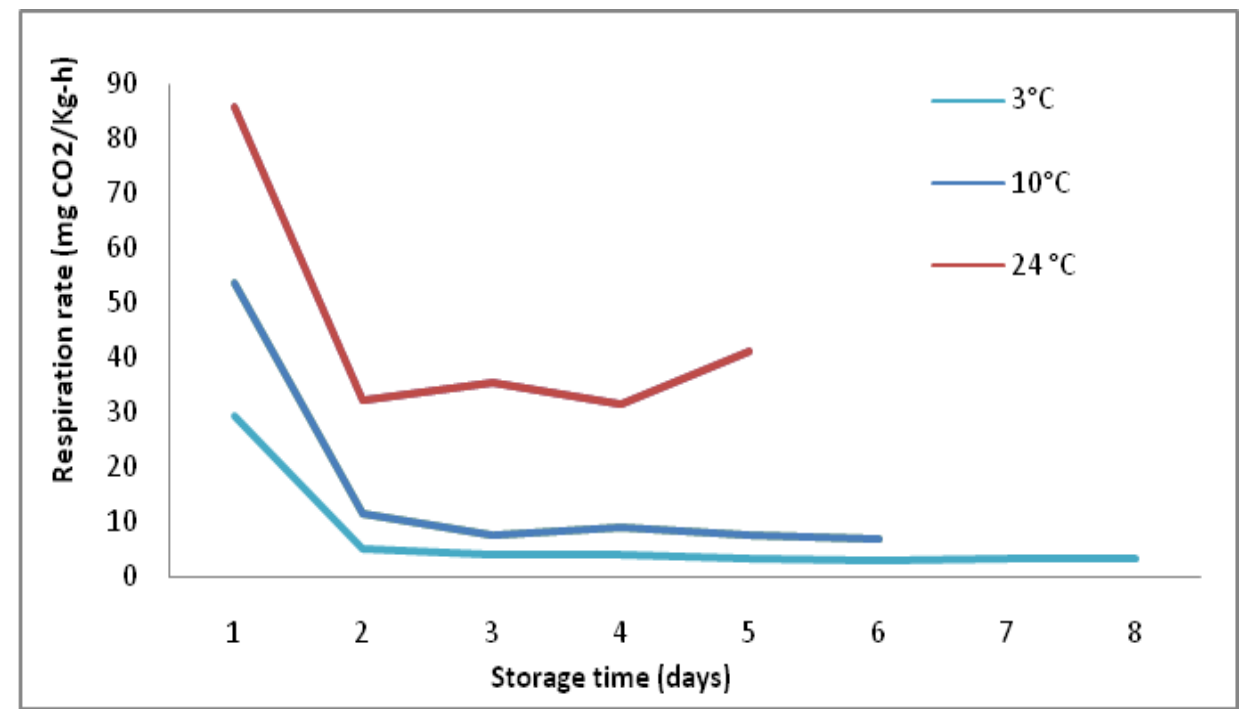

From the values, it was observed that the respiration rates for $\mathrm{CO}_{2}$ concentration at any temperature with increase in the time interval decreased. The $\mathrm{CO}_{2}$ production rate was faster at $24^{\circ} \mathrm{C}$ than the other temperatures.

The reduction of respiration rates was noted at $10^{\circ} \mathrm{C}$ and $3^{\circ} \mathrm{C}$. At $10^{\circ} \mathrm{C}$ there was a significant decrease of $\mathrm{CO}_{2}$ production rate and at $3^{\circ} \mathrm{C}$ there were fluctuations in the $\mathrm{CO}_{2}$ values which may be due to the occurrence of chilling injury of tissues. The respiration rate at different temperature is represented in figure 5 .

From the result conclusion can be drawn that, the $\mathrm{CO}_{2}$ release and $\mathrm{O}_{2}$ consumption rates were faster during the initial hours of storage. It is clear that at $24{ }^{\circ} \mathrm{C}$, the respiration rate of field beans gradually decreased after 30 hours (Figs 3 and 4). Such a decline may be due to the biochemical reactions taking place within in the substrate. At 10 and $3{ }^{\circ} \mathrm{C}$ there was a gradual decrease in the respirate rate, which indicated that low temperature is helpful to slow down the respiration process and could keep the tissues alive for longer periods.

\section{References}

Bhukan Jyothi Mahadu, 2008. M. Tech. (Agril. Engg.) Thesis, Studies on shelf life extension of Capsicum (Capsicum Annuиm L.) using modified atmosphere packaging, Department of Agricultural Engineering, University of Agricultural Sciences, Bangalore-65.

Dixon, J., Smith, D.B. and Elmsly., 2004. Fruit age, storage temperature and maturity effects on Hass Avocado fruit quality and ripening. New Zealand Avocado Growers Association Annual Research Report. 5(4): 47-53.

Khan, M.A., and I. Ahmad, 2005. Morphological studies on physical changes in apple fruit after storage at room temperature. J. Agric.

Lakakul, R., Beaudry RM, Hernandez RJ 1999. Modeling Respiration of Apple Slices in Modified-Atmosphere Packages. J Food Sci 64: 105-110.

Lee, S.K., and Kader A.A., 2000. Pre-harvest and postharvest factors influencing Vitamin C content of horticultural crops. Postharvest Biol. Technol, 20(2): 
207-220.

Purseglove, J. W., 1968. Tropical Crops, Dicotyledons, Vol L London, UK; Longmans Greens and Company Ltd. P. 273-276.

Ramachandra, M., 1995. Thesis- Diffusion Channels for Broccoli Storage. Dept. of Agr, and Biosystems Engineering,
Macdonald Campus of McGill University, Ste Anne de Beilevue, Canada

Yang, C.C., Chinnan MS., 1988. Modeling the Effect of $\mathrm{O}_{2}$ and $\mathrm{CO}_{2}$ on Respiration and Quality of Stored Tomatoes. Transactions of the ASABE 31: 09200925.

\section{How to cite this article:}

Nisha, R., C. Nickhil and Ramachandra, M. 2017. Studies on Respiration Rate of Field Beans at Different Temperatures. Int.J.Curr.Microbiol.App.Sci. 6(10): 3346-3353. doi: https://doi.org/10.20546/ijcmas.2017.610.391 